\title{
Factors affecting diagnostic value of the fine-needle aspiration biopsy applied for parotid tumors
}

\author{
Parotis tümörlerinde ince iğne aspirasyon biyopsisinin tanısal değerini etkileyen faktörler \\ Umut Kaygusuz', Samet Özlügedik², Ayşe Seçil Kayalı Dinç³, Tolga Dinç \\ ${ }^{1}$ Department of Otorbinolaryngology, Dr. Sami Ulus Children's Hospital, Ankara, Turkey \\ ${ }^{2}$ Department of Otorbinolaryngology, Dr. Abdurrabman Yurtaslan Ankara Oncology Training and Research Hospital, Ankara, Turkey \\ ${ }^{3}$ Department of Otorbinolaryngology, Ankara Numune Training and Research Hospital, Ankara, Turkey
}

\begin{abstract}
Objective: Our aim was to evaluate factors affecting diagnostic value of the fine-needle aspiration biopsy (FNAB) used for the diagnosis of parotid tumors.

Methods: This study included 76 patients with available data who had been operated between 2005 and 2011 in Ankara Numune Training and Research Hospital. Impact of parameters which might affect the diagnostic value of preoperative FNAB results such as location, size, characteristics (cystic or solid) of the tumors, and use of ultrasonographic guidance (if any) were analyzed.

Results: Sensitivity (63\%), specificity (98\%), discriminative diagnostic value for benign $(93 \%)$ and malignant $(87.5 \%)$ tumors and tumorspecific diagnosis $(42.1 \%)$ related to FNABs performed were also estimated. Ultrasound-guided FNAB increased adequacy of the material retrieved. A significant correlation has not been detected between diagnostic value of FNAB, location and size of the tumor.

Conclusion: FNAB appears to be a safe, cost-effective and minimally invasive method, which provides preoperative information for both the patient and the physician about parotid tumors with diagnostic accuracy over 90 percent.
\end{abstract}

Key words: Parotid, fine-needle aspiration biopsy, tumor.

Salivary gland tumors comprise of $2-3 \%$ of whole body tumors and $3-12 \%$ of head and neck tumors. ${ }^{[1]}$ Though these tumors are rarely seen, they show especially histological variations. ${ }^{[2]}$ Generally, it is clinically difficult to discriminate between benign and malignant tumors. Slowly growing, mobile and painless mass is usually a common characteristic for benign and malignant tumors. ${ }^{[\beta]}$

\section{Özet}

Amaç: Parotis tümörlerinin tanısında kullanılan ince iğne aspirasyon biyopsisinin (İ̈AB) tanısallığını etkileyen faktörlerin değerlendirilmesi amaçlanmıștır.

Yöntem: Bu çalışmaya 2005 ile 2011 yılları arasında Ankara Numune Eğitim ve Araşturma hastanesinde opere edilmiş olan ve verilerine ulaş1labilinen 76 hasta dahil edildi. Hastaların preoperatif IİAB'lerinin tanısallığını etkileyebilecek, tümörün lokalizasyonu ve boyutu, kistik ya da solid oluşu, IİAB yapılırken ultrasonografinin kullanılıp kullanılmaması gibi parametrelerin İ̈AB'nin tanısallığ 1 üzerine etkinlikleri incelendi.

Bulgular: Yapılan IİAB'lerin sensivitesi \%63, spesifitesi \%98, malignant-benign tümör tanısı koyabilme oranı benign tümörlerde \%93, malignant tümörlerde \%87.5, tümöre spesifik tam tanı kayabilme oranı \% 42.1 olarak bulundu. İnce iğne aspirasyon biyopsisi yapılırken kullanılan ultrasonografinin sitoloji için alınan materyalin yeterliliğini artturdığı görüldü. Tümörün yerleşim yeri ve boyutuyla İंAB'nin tanısal değeri arasında anlamlı bir ilişki saptanmadı.

Sonuç: İnce iğne aspirasyon biyopsisinin parotis tümörlerinde \%90 üzerinde tanısal doğrulukta bilgi verdiği, preoperatif hasta ve hekim için tedaviyi belirlemede güvenli, ucuz ve minimal invaziv bir yöntem olduğu görülmektedir.

Anahtar sözcükler: Parotis, ince iğne aspirasyon biyopsisi, tümör.

Clinical symptoms, signs and imaging techniques used in the preoperative diagnosis of salivary gland tumors can not provide adequate information for histopathological diagnosis of the tumor. However, fine-needle aspiration biopsy (FNAB) is a sensitive and widely used procedure in the diagnosis of salivary glands with established value. For years, debates about the use of FNAB in the diagnosis of
Correspondence: Ayşe Seçil Kayalı Dinç, MD. Department of Otorhinolaryngology, Ankara Numune Training and Research Hospital, Altındağ, Ankara, Turkey. e-mail: secilkayali81@yahoo.com

Received: June 14, 2013; Accepted: August 5, 2013; Published online: January 29, 2014
Online available at:

www.jmedupdates.org doi:10.2399/jmu.2013003006 QR code: 
mass lesions stemming from salivary glands are still continuing. ${ }^{[4,5]}$ In many studies, degrees of sensitivity and specificity of FNAB have been reported. Generally speaking, degrees of its sensitivity and specificity vary between 85 $99 \%$ and $96-100 \%$, respectively. ${ }^{[5,6]}$

In the present study, factors affecting the diagnostic value and worth of FNAB used in the diagnosis of parotid tumors have been analyzed.

\section{Materials and Methods}

In this study, 84 patients who had been operated for a parotid mass lesion between the years 2005 and 2011 in 1st ENT Clinics of Ankara Numune Training and Research Hospital were retrospectively analyzed and 76 patients who had undergone preoperative FNAB with available data were included in the study.

Data of all patients about preoperative radiological and cytological analyses, surgical techniques used, postoperative histopathologic diagnoses, complications and followup were retrieved and evaluated. This study was conducted in accordance with the decree of the Local Ethics Committee and after obtaining enlightened consent forms from all patients.

The impact of FNABs performed with or without the aid of ultrasound (US) guidance on adequacy and diagnostic value of aspirates collected by FNABs, structure of tumors delineated by US (solid, cystic or mixed), rates of diagnostic changes caused by FANB, its discriminative capability in differentiating between malignant and benign tumors and its success in the establishment of tumor-specific diagnosis and also the effect of dimensions and locations of parotid masses on diagnostic value of FNAB results were analyzed. Finally interrelationship between FNAB results and these retrieved data and also its preoperative significance on the choice of the surgical alternative were investigated.

All statistical analyses were realized using SPSS 10.0 statistical software package (SPSS Inc. Chicago, IL, USA). A p value of 0.005 was considered to be statistically significant.

\section{Results}

Preoperative ultrasonographic examinations performed on the patients with parotid masses included in the study detected parotid tumors with diameters of $0-2 \mathrm{~cm}(19.7 \% ; 15 / 76)$, $2-4 \mathrm{~cm}(52.6 \% ; 40 / 76)$ and $\geq 4 \mathrm{~cm}(27.6 \% ; 21 / 76)$ with rates indicated within parentheses. Parotid tumors were seen in the superficial $(73.7 \% ; 56 / 76)$ or deep $(14.5 \% ; 11 / 76)$ parotid lobes or both (11.8\%; 9/76). Ultrasonographic examinations detected solid, cystic or mixed tumors in 68.4 $\%(52 / 76), 7.9 \%(6 / 76)$ and $23.7 \%(18 / 76)$ of the patients respectively.

During preoperative period, FNABs were performed under polyclinic conditions with or without the guidance of US in $52.6 \%(40 / 76)$ and $47.4 \%(36 / 76)$ of the patients, respectively. FNAB results also revealed benign (75\%; $57 / 76)$ and malignant tumors $(10.5 \%, 8 / 76)$ and $14.5 \%$ (11/76) of them were non-diagnostic: postoperative histopathological results were reported as benign (81.6\%; $62 / 76)$ or malignant $(18.4 \% ; 14 / 76)$ tumors. Results of histopathologic examinations of parotid gland specimens are indicated in Table 1.

Concordance between the results of FNAB and postoperative histopathological examinations (i.e. discriminative capability of FNAB in differentiating between benign and malignant masses): Comparison of the concordance of the results of preoperative FNAB cytologies and postoperative histopathologic examinations as for discriminative capability in differentiating between malignant and benign masses is shown in Table 2 . A certain percentage $(27.3 \% ; 3 / 11)$ of non-diagnostic tumors as evaluated by FNAB was found to be malignant mass lesions after histopathologic examinations. Majority of malignant $(87.5 \%$; $7 / 8)$ and benign $(93 \% ; 53 / 57)$ tumors determined based on FNAB results were also confirmed by histopathological examinations. A statistically significant correlation was found between preoperative FNAB and postoperative histopathology results in discrimination between benign and malignant tumors ( $\mathrm{p}<0.001)$. Sensitivity and specificity of FNAB results

Table 1. Postoperative histopathological results

\begin{tabular}{llc}
\hline & Histopathological diagnosis & $\mathbf{n}(\%)$ \\
\hline Benign & Pleomorphic adenoma & $32(42.1 \%)$ \\
tumors & Warthin's tumor & $15(19.7 \%)$ \\
& Basal cell adenoma & $5(6.6 \%)$ \\
& Reactive lymphoid hyperplasia & $4(5.3 \%)$ \\
& Chronic sialoadenitis & $3(3.9 \%)$ \\
& Lipoma & $2(2.6 \%)$ \\
& Pilomatrixoma & $1(1.3 \%)$ \\
\hline Malignant & Adenocarcinoma & $4(5.3 \%)$ \\
tumors & Myoepithelial carcinoma & $2(2.6 \%)$ \\
& Adenocystic carcinoma & $2(2.6 \%)$ \\
& Asinic cell carcinoma & $1(1.3 \%)$ \\
& Adenosquamous carcinoma & $1(1.3 \%)$ \\
& Squamous cell carcinoma & $1(1.3 \%)$ \\
& Malignant melanoma & $1(1.3 \%)$ \\
& Lymphoma & $1(1.3 \%)$ \\
& Papillary cystic tumor of the salivary gland & $1(1.3 \%)$ \\
\hline
\end{tabular}


are given in Table 3. Eight non-diagnostic tumors assessed based on FNAB results were revealed to be three pleomorphic adenomas (PAs), two cases of Warthin's tumor (WT), two lymphoid hyperplasias and one basal cell adenoma (BCA) after their histopathological examinations. Only one case of malignancy based on FNAB results was reported as PA after histopathological examination. Histopathologically reported malignant tumors classified as benign neoplasms according to FNAB results were noted by us to be acinic cell carcinoma (ACC), malign lymphoma, papillary cystic salivary gland tumor and myoepithelial carcinoma ex-PA.

Evaluation of the factors affecting cytopathological concordance in tumors whose FNAB results and postoperative histopathologic diagnoses matched completely: In patients whose histopathologic diagnoses could be firmly established during examination of preoperatively obtained FNAB specimens, complete cytopathological concordance with FNAB results was analyzed. Nearly all of the cases demonstrating complete cytopathological concordance consisted of benign tumors, while in only one of the malignant tumors, diagnosis of malignant melanoma could be made with certainty by the examination of FNAB specimens. Thirty-one parotid neoplasms (evaluated as benign tumors based on FNAB results) demonstrated complete cytopathological concordance were diagnosed as PA $(n=20)$, WT $(\mathrm{n}=8)$, lipoma $(\mathrm{n}=2)$ and reactive lymphoid hyperplasia $(\mathrm{n}=1)$. In $42.1 \%$ of all patients whose FNAB results and postoperative histopathology reports were completely alike, establishment of accurate and precise diagnosis by examination of FNAB specimens was highly probable for benign tumors relative to malignant ones. The relationship between tumors with similar FNAB and postoperative histopathological results (complete cytopathological concordance) and their anatomical structure (solid, cystic or mixed) is given in Table 4. A significant correlation could not be found between tumoral characteristics on one hand and complete concordance between FNAB and cytopathologic results on the other side $(\mathrm{p}=0.358)$. Complete cytopathological concordance was evaluated with respect to the application method of the FNAB procedure (with or without US guidance) and tumoral structure (benign or malign), and distribution of the values of complete concordance between FNAB and cytopathological results are given in Table 5. In US-guided FNABs, complete cytopathological concordance was achieved in $37.5 \%$ (9/24) of solid, $25 \%$ $(1 / 4)$ of cystic and $50 \%(6 / 12)$ of mixed tumors, while FNABs performed without the aid of US demonstrated complete cytopathological concordance in 46\% (13/28) of solid and 50\% (3/6) of mixed tumors. Complete cytopathological concordance was not observed in none of the cystic
Table 2. Comparison of the concordance of fine-needle aspiration biopsy cytologies and postoperative histopathologic examinations as for discriminative capability in differentiating between malignant and benign masses.

\begin{tabular}{lccc}
\hline & $\begin{array}{c}\text { Pathological } \\
\text { diagnosis: } \\
\text { benign }\end{array}$ & $\begin{array}{c}\text { Pathological } \\
\text { diagnosis: } \\
\text { malignant }\end{array}$ & $\begin{array}{c}\mathbf{p} \\
\text { value }\end{array}$ \\
\hline Nondiagnostic & $8(72.7 \%)$ & $3(27.3 \%)$ & \\
Malignant & $1(12.5 \%)$ & $7(87.5 \%)$ & $\mathrm{p}<0.001$ \\
Benign & $53(93 \%)$ & $4(7 \%)$ & \\
Total & $62(81.6 \%)$ & $14(18.4 \%)$ & \\
\hline
\end{tabular}

Table 3. Sensitivity and specificity of fine-needle aspiration biopsy results.

\begin{tabular}{lc}
\hline & 95\% confidence limits \\
\hline Sensitivity & 63 \\
Specificity & 98 \\
Wrong negative & 36 \\
Wrong positive & 0.1 \\
Positive predictive value & 89 \\
Negative predictive value & 91 \\
\hline
\end{tabular}

Table 4. The relationship between tumors with similar fine-needle aspiration biopsy and postoperative histopathological results (complete cytopathological concordance) and their anatomical structure (solid, cystic or mixed).

\begin{tabular}{lccc}
\hline & $\begin{array}{c}\text { Complete } \\
\text { cytopathological } \\
\text { concordance } \\
\text { present }\end{array}$ & $\begin{array}{c}\text { Complete } \\
\text { cytopathological } \\
\text { concordance } \\
\text { absent }\end{array}$ & $\begin{array}{c}\mathbf{p} \\
\text { value }\end{array}$ \\
\hline Solid & $22(68.8 \%)$ & $30(68.2 \%)$ & \\
Cystic & $1(3.1 \%)$ & $5(11.4 \%)$ & $\mathrm{p}=0.358$ \\
Mixed & $9(28.1 \%)$ & $9(20.5 \%)$ & \\
Total & $32(100 \%)$ & $44(100 \%)$ & \\
\hline
\end{tabular}

tumors. Even though US- guidance increases diagnostic value of FNAB in cystic tumors, complete concordance between FNAB and cytopathological results was not statistically significantly influenced whether FNAB is performed under US guidance or not ( $\mathrm{p} 1=0.626, \mathrm{p} 2=0.423)$.

Evaluation of the complete concordance between FNAB and postoperative histopathologic results with respect to diameter of the tumoral masses (complete cytopathologic concordance): Comparison between complete cytopathologic concordance and diameter of the 
Table 5. Fine-needle aspiration biopsy procedure (with or without ultrasound guidance) and tumoral structure (benign or malign), and distribution of the values of complete concordance between fine-needle aspiration biopsy and cytopathological results.

\begin{tabular}{|c|c|c|c|c|c|c|}
\hline & \multicolumn{2}{|c|}{$\begin{array}{c}\text { Concordance between FNAB (with US guidance) } \\
\text { and cytopathological results ( } \mathrm{p} 1)\end{array}$} & \multicolumn{2}{|c|}{$\begin{array}{c}\text { Concordance between FNAB (with US guidance) } \\
\text { and cytopathological results (p2) }\end{array}$} & \multirow[t]{2}{*}{ p1 } & \multirow[t]{2}{*}{ p2 } \\
\hline & Present & Absent & Present & Absent & & \\
\hline Cystic & $1(25 \%)$ & $3(75 \%)$ & $0(0 \%)$ & $2(100 \%)$ & \multirow{3}{*}{0.626} & \multirow{3}{*}{0.423} \\
\hline Mixed & $6(50 \%)$ & $6(50 \%)$ & $3(50 \%)$ & $3(50 \%)$ & & \\
\hline Total & 16 & 24 & 16 & 20 & & \\
\hline
\end{tabular}

FNAB: fine-needle aspiration biopsy.

parotid tumors was done, and any statistically significant correlation between them was not detected $(\mathrm{p}=0.580)$ (Table 6).

Comparison of tumoral location, FNAB results and postoperative complete histopathologic concordance: Comparative data about location of the tumor, FNAB results and complete postoperative histopathologic concordance are given in Table 7. Comparison of tumoral location and cytopathologic concordance was analyzed and complete cytopathologic concordance was seen in cases with superficial $(46.4 \% ; 26 / 56)$, deep $(27.3 \% ; 3 / 11)$ and both superficial and deep thyroid lobe tumors $(33.3 \% ; 3 / 9)$. A statistically significant correlation could not be found between location of the tumor and complete cytopathologic concordance $(\mathrm{p}=0.426)$. Complete concordance between the results of US-guided FNAB and postoperative histopathologic examinations with respect to location of the tumor (complete cytopathologic concordance) was detected in 41.4\% (12/29) of superficial, in $40.0 \%(2 / 5)$ of deep and in $33.3 \%(2 / 6)$ of both superficial and deeply located tumors. The corresponding rates for FNABs performed without US guidance were found to be $51.9 \%(14 / 27), 16.7 \%(1 / 6)$ and $33.3 \%(1 / 3)$, respectively. Results of FNABs performed with or without US-guidance (p2) did not demonstrate statistically significant differences as for location of the tumor (p1). $(\mathrm{p} 1=0.426$, $\mathrm{p} 2=0.935$ ).

Comparison of tumoral characteristics, use of US guidance and adequacy (or inadequacy) (diagnostic non-diagnostic) of the FNAB specimen for histopathologic examination: Solid, cystic and mixed structure of the tumors of $40(52.6 \%)$ patients who had undergone USguided FNAB and diagnostic value of FNAB material were shown in Table 8. Implementation of US increases diagnostic value of FNAB. Especially in mixed tumors, diagnostic value of US-guided FNABs was found to be statistically significantly higher than those applied without the aid of US $(\mathrm{p}=0.003)$.
Histopathologic results of 11 (14.5\%) patients with non-diagnostic FNAB obtained in our study were given in Table 9.

\section{Discussion}

The most important problem encountered in the diagnosis of parotid tumors lies in the certainty of our predictive diagnosis made by available imaging modalities and examination techniques. Indeed, preemptive recognition of the nature of the mass lesion (benign or malign) beforehand will enable us to give sufficient preoperative information to the patient

Table 6. Comparison between complete cytopathologic concordance and diameter of the tumor.

\begin{tabular}{lccc}
\hline & $\begin{array}{c}\text { Complete } \\
\text { cytopathological } \\
\text { concordance } \\
\text { present }\end{array}$ & $\begin{array}{c}\text { Complete } \\
\text { cytopathological } \\
\text { concordance } \\
\text { absent }\end{array}$ & $\begin{array}{c}\text { p } \\
\text { value }\end{array}$ \\
\hline $\mathrm{T}=0-2 \mathrm{~cm}$ & $5(33.3 \%)$ & $10(66.7 \%)$ & \\
$\mathrm{T}=2-4 \mathrm{~cm}$ & $19(47.5 \%)$ & $21(52.5 \%)$ & $\mathrm{p}=0.580$ \\
$\mathrm{~T}>4 \mathrm{~cm}$ & $8(38.1 \%)$ & $13(61.9 \%)$ & \\
Total & $44(57.9 \%)$ & $32(42.1 \%)$ & \\
\hline
\end{tabular}

Table 7. Comparative data about location of the tumor, fine-needle aspiration biopsy results and complete postoperative histopathologic concordance.

\begin{tabular}{lccc}
\hline & $\begin{array}{c}\text { Complete } \\
\text { cytopathological } \\
\text { concordance } \\
\text { present }\end{array}$ & $\begin{array}{c}\text { Complete } \\
\text { cytopathological } \\
\text { concordance } \\
\text { absent }\end{array}$ & $\begin{array}{c}\text { p } \\
\text { value }\end{array}$ \\
\hline $\begin{array}{l}\text { Superficial lobe } \\
\text { Deep lobe }\end{array}$ & $26(46.4 \%)$ & $30(53.6 \%)$ & \\
$\begin{array}{l}\text { Superficial+deep } \\
\text { thyroid lobe }\end{array}$ & $3(27.3 \%)$ & $8(72.7 \%)$ & $\mathrm{p}=0.426$ \\
Total & $32(42.1 \%)$ & $6(66.7 \%)$ & \\
\hline
\end{tabular}


Table 8. Solid, cystic and mixed structure of the tumors of patients who had undergone US-guided fine-needle aspiration biopsy and diagnostic value of fine-needle aspiration biopsy material.

\begin{tabular}{|c|c|c|c|c|c|c|c|c|c|c|}
\hline & \multicolumn{5}{|c|}{ US-guided FNAB } & \multicolumn{5}{|c|}{ Non-US-guided FNAB } \\
\hline & \multicolumn{2}{|c|}{ Diagnostic FNAB } & \multicolumn{2}{|c|}{ Nondiagnostic FNAB } & \multirow[t]{2}{*}{$p$ value } & \multicolumn{2}{|c|}{ Diagnostic FNAB } & \multicolumn{2}{|c|}{ Nondiagnostic FNAB } & \multirow[t]{2}{*}{$p$ value } \\
\hline & $n$ & (\%) & $\mathbf{n}$ & $(\%)$ & & n & $(\%)$ & $\mathbf{n}$ & $(\%)$ & \\
\hline Cystic & 2 & 50.0 & 2 & 50.0 & & 1 & 50.0 & 1 & 50.0 & \\
\hline Mixed & 12 & 100.0 & 0 & 0.0 & & 5 & 83.3 & 1 & 16.7 & \\
\hline Total & 37 & 92.5 & 3 & 7.5 & & 28 & 77.8 & 8 & 22.2 & \\
\hline
\end{tabular}

FNAB: fine-needle aspiration biopsy.

about his/her disease. The potential risk of malignancy if the patient declines surgical intervention, progression of the disease, feasibility of complete eradication of the disease, knowledge of non-surgical alternatives are very important issues both for the patient and the physician. On the other hand, potential complications of the parotid surgery and surgical morbidity are not easily acceptable and accountable phenomena both for the patient and the surgeon in cases where the physician has no idea about the diagnosis.

FNAB is a sensitive technique used widely in the salivary gland tumors with proven value. Especially preoperative recognition of the lesion and planning the appropriate treatment are very important and useful procedures. FNAB can discriminate between patients requiring a small-scale or more extensive, radical surgery. Besides, it can determine salivary gland diseases amenable to non-surgical therapy. Thus, the patient will not expose to unnecessary morbidities. Besides, the patient will not be exposed to morbidities, and harmful effects of inadequate cure, use of unnecessary diagnostic and therapeutic procedures, In addition, problems such as loss of limited financial resources and waste of time will be obviated. Debates about use of FNAB in the diagnosis of masses originating from salivary glands are continuing for years. ${ }^{[4,5]}$

In one of the first FNAB series of 288 cases published by Spiro et al. in 1975, the authors disregarded the significance of FNAB because of its misleading outcomes and emphasized that a parotid mass which does not decrease in size or gradually becomes larger is a candidate for surgical treatment. Therefore, they concluded that FNAB was not an indispensable diagnostic tool for the decision-making process for surgery. ${ }^{[7]}$

FNAB results of 160 salivary gland tumors were published in 1990 by Shaha et al. and 84 of them were related to parotid tumors. The authors indicated rates of diagnostic accuracy over $90 \%$ and emphasized the inadequacy of
FNAB in discriminating chronic inflammatory conditions as sialaadenitis from stasis. ${ }^{[8]}$

In a series of 187 cases with salivary gland FNAB data published by Nettle et al. in 1989, the authors indicated that FNAB could specifically diagnose benign tumors more accurately, while FNAB was useful in differentiating malignant parotid tumors from benign lesions and inflammatory diseases of the parotid gland. ${ }^{[9]}$

All of our 76 patients operated for parotid tumors had undergone preoperative FNAB procedures. FNAB is an indispensable procedure for the investigation of head and neck masses including salivary gland masses detected in our and many ENT-Head and Neck Surgery clinics worldwide. FNAB can be performed using 22-25 gauge needles under polyclinic conditions and US-guidance. To increase diagnostic accuracy of FNAB, adequate amount of tissue suitable for cytologic examination should be aspirated using FNAB needles. Because of hypervascularity of head and neck region, aspirates are contaminated by blood components which in turn complicate establishment of diagnosis by FNAB. Use of large bore needles traumatizes vascular structure, with resultant contamination of aspirate by blood components. This complication decreases diagnostic adequacy of FNAB and damages tumoral tissue, which might

Table 9. Histopathologic results of patients with non-diagnostic fineneedle aspiration biopsy.

\begin{tabular}{ll}
\hline Histopathological diagnosis & $\mathbf{n}$ \\
\hline Warthin's tumor & 3 \\
Pleomorphic adenoma & 2 \\
Basal cell adenoma & 2 \\
Squamous cell carcinoma & 1 \\
Reactive lymphoid hyperplasia & 2 \\
Adenocystic carcinoma & 1 \\
\hline
\end{tabular}


falsify postoperative histopathologic diagnosis of the tumor. With use of small-bore needle tips, sufficient amount of aspirate can not be retrieved which decrease diagnostic value of FANB. This issue and suspected seeding of tumoral components in salivary gland tumors are frequently expressed by investigators who argued against routine use of FANB in salivary gland tumors. ${ }^{[5]}$ Mukunyadzi et al. analyzed 94 salivary gland specimens as for the presence of infarction, bleeding, tumoral seeding along the entry route of the needle and fibrosis and reported that 25 -gauge needles are safe and histological alterations induced by FNAB procedure did not complicate establishment of diagnosis in none of the cases. ${ }^{[10]}$ Histopathology reports of the patients operated by us did not indicate the presence of any histological alterations caused by FNAB, which complicated establishment of diagnosis.

In their large-scale studies, many authors have revealed FNAB as a proper diagnostic tool. In most of these series diagnostic accuracy rates climbed to 95 percent. Its sensitivity and specificity in the detection of benign tumors were found to be $88-98 \%$ and at least $94 \%$, respectively. Its accuracy rate in the diagnosis of especially $\mathrm{PA}$ is over 90 percent. ${ }^{[5]}$ FNAB can not yield very accurate results in the discrimination among many malignant tumors. Indeed, in our study, sensitivity and specificity of FNAB were found to be $63 \%$, and $98 \%$, respectively. Postoperative histopathology reports preoperative FNAB results of 53 out of 54 patients with benign postoperative histopathology results were also reported as benign. Also in our study, diagnostic performance of FNAB appears to be very successful in the detection of benign tumors.

Some publications have asserted that US-guided FNAB facilitated retrieval of biopsy material from non-palpable or heterogenous tumors. ${ }^{[11]}$ We performed US-guided FNABs in $52.6 \%$ of our patients, while $47.4 \%$ of the biopsies were performed without the aid of US, under polyclinic conditions. In $92.5 \%$ of the US-guided FNABs adequate material can be obtained for cytologic examination, while only $77.8 \%$ of the FNABs performed without the aid of US could yield adequate material. Though biopsy material retrieval rates between two groups are not very different, US-guidance especially facilitates easy access into nonpalpable masses.

Fine-needle aspiration biopsy is a very effective technique in discriminating between malignant and benign salivary gland tumors, but it is not comparatively effective in establishing precise histopathological diagnosis. In many studies, FNAB had a tumor-specific diagnostic value rang- ing between 25 -and 85 percent. ${ }^{[4]}$ Preoperatively, establishment of tumor-specific diagnosis using FNAB is termed as complete cytopathologic concordance (tumor-specific diagnosis). In a study performed in Turkey by Mahmudova et al. in 2010, the rate of complete cytopathologic concordance was reported as 29 percent. ${ }^{[12]}$ In a study conducted by Deneuve et al. in France (2010) with 78 cases, diagnostic accuracy of FNAB was reported as $94 \%$ with non-diagnostic results obtained in $10 \%$ of the cases. ${ }^{[13]}$

In our study, FNAB-detected malignant and benign tumors were histopathologically confirmed in 87.5 and $93 \%$ of the cases, respectively. When non-diagnostic results were excluded, diagnostic value of FNAB was found to be 92 percent. FNAB and cytopathology results were in complete concordance in $42.1 \%$ of the cases. The reason for this low rate of concordance is especially related to requirement for tissue specimens to determine criteria of malignancy and inadequate amount of tissue retrieved for cytological examinations rather than misdiagnoses.

Despite scarce number of literature studies related to US-guided FNAB procedures, Feld et al. reported that use of US had facilitated application of FNAB procedure in heterogenous and non-palpable masses. ${ }^{[11]}$ In our study, we analyzed tumors with solid, cystic and mixed components and adequacy of FNAB aspirate material and adequacy of FNAB was statistically significantly improved with concominant use of US ( $\mathrm{p}=0.003)$. Rates of complete concordance between cytopathologic results with respect to diameters and locations of the parotid tumors included in our study were also analyzed. A significant correlation could not be found between diameter of the tumor and complete cytopathologic concordance $(\mathrm{p}=0.580)$. Complete cytopathologic concordance of FNAB was examined and any statistically significant difference was not found between the results of FNABs applied with or without US guidance $(\mathrm{p}=0.426)$.

\section{Conclusion}

Fine-needle aspiration biopsy is an easily applicable, reliable and cost-effective diagnostic tool. However, it can be performed under polyclinic conditions with or without USguidance, US increases adequacy of the material retrieved. Although preoperative FNAB does not establish specific diagnosis precisely with very high probability, it can especially discriminate between malignant and benign tumors in more than $90 \%$ of the cases. With these advantages FNAB is currently the best preoperative diagnostic tool in parotid tumors.

Conflict of Interest: No conflicts declared. 


\section{References}

1. Cuhruk Ç, Yılmaz O. Tükrük bezi hastalıkları. In: Çelik O, editor. Kulak burun boğaz hastalıkları ve baş boyun cerrahisi. 1. baskı. İstanbul: Turgut Yayıncilık; 2002. p. 570-84.

2. Hoşal Ş, Sungur A, Özyar E. Tükrük bezi kanserleri. In: Engin K, Erişen L, editors. Baş-boyun kanserleri. Bursa: Nobel Tip Kitabevi; 2003. p. 411-32.

3. Spiro RH. Salivary neoplasms: overview of a 35-year experience with 2,807 patients. Head Neck Surg 1986;8:177-84.

4. Zbären P, Schär C, Hotz MA, Loosli H. Value of fine-needle aspiration cytology of parotid gland masses. Laryngoscope 2001;111 (11 Pt 1):1989-92.

5. Hanna EY, Lee S, Fan CY, Suen JY. Tükrük bezlerinin benign tümörleri. In: Cummings CW, Flint PW, Harker LA, et al., editors. Cummings otolaringoloji baş ve boyun cerrahisi. 4. Türkçe baskı. Ankara: Güneş Tıp Kitapevi; 2007. p. 1348-77.

6. Al-Khafaji BM, Afify AM. Salivary gland fine needle aspiration using the ThinPrep technique: diagnostic accuracy, cytologic artifacts and pitfalls. Acta Cytol 2001;45:567-74.
7. Spiro RH, Huvos AG, Strong EW. Cancer of the parotid gland. A clinicopathologic study of 288 primary cases. Am J Surg 1975;130: 452-9.

8. Shaha AR, Webber C, DiMaio T, Jaffe BM. Needle aspiration biopsy in salivary gland lesions. Am J Surg 1990;160:373-6.

9. Nettle WJ, Orell SR. Fine needle aspiration in the diagnosis of salivary gland lesions. Aust N Z J Surg 1989;59:47-51.

10. Mukunyadzi P, Bardales RH, Palmer HE, Stanley MW. Tissue effects of salivary gland fine-needle aspiration. Does this procedure preclude accurate histologic diagnosis? Am J Clin Pathol 2000;114: 741-5.

11. Feld R, Nazarian LN, Needleman L, et al. Clinical impact of sonographically guided biopsy of salivary gland masses and surrounding lymph nodes. Ear Nose Throat J 1999;78:905-12.

12. Mahmudova R, Akyıldız S, Midilli R. Parotis kitlelerinde ince iğne aspirasyon biyopsisinin tanısal değeri. Ege Journal of Medicine (Izmir) 2010;49:83-6.

13. Deneuve S, Quesnel S, Depondt J, et al. Management of parotid gland surgery in a university teaching hospital. Eur Arch Otorhinolaryngol 2010;267:601-5.

This is an open access article distributed under the terms of the Creative Commons Attribution-NonCommercial-NoDerivs 3.0 Unported (CC BYNC-ND3.0) Licence (http://creativecommons.org/licenses/by-nc-nd/3.0/) which permits unrestricted noncommercial use, distribution, and reproduction in any medium, provided the original work is properly cited.

Please cite this article as: Kaygusuz U, Özlügedik S, Kayalı Dinç AS, Dinç T. Factors affecting diagnostic value of the fine-needle aspiration biopsy applied for parotid tumors. J Med Updates 2013;3(3):135-141. 